Tyndale Bulletin 69.1 (2018) 149-152

\title{
RETRIBUTION IN THE CANONICAL PSALTER ${ }^{1}$
}

\author{
Steffen G. Jenkins \\ (sjenkins@ust.ac.uk)
}

Prayers against enemies have caused concern to readers of the Psalms since earliest times. This dissertation approaches such prayers in their context within the Psalter as a book, paying attention to the shape and structure of the whole Psalter, and asks whether such an approach can shed light on a close reading of prayers for retribution.

We begin with an overview of historic responses, examining authors in a variety of cultural and confessional settings (Jewish and Christian; patristic, medieval, Reformers, Puritans and Moderns; European, American, African, Asian; Roman Catholic, Lutheran, Reformed, Dispensational, and Adventist). We find everything from a priori ethical rejection through to a cautious appropriation of such prayers. Surprisingly, ethical qualms are not determined by context: persecuted believers in Africa and pre-modern commentators are as likely to be wary of these texts as contemporary westerners because of a perceived tension with the ethics of the New Testament. Some prayers seem built on the antithesis of the gospel of grace and especially to betray selfrighteousness.

We examine the history of canonical readings of the Psalter and note that it is ancient, contrary to recent scholarly accounts. Higher criticism marked a low point in whole-Psalter readings, rather than predating them altogether. We find a lack of studies that engage the question of imprecations within their context in the Psalter: almost every other interpretive grid has been tried instead.

Psalms 1 and 2 are often seen as introductory and do indeed introduce enemies and retribution. Moreover, Psalm 3 immediately introduces David at prayer against his enemy Absalom. The promises and warnings of Psalms 1 and 2 concerning the righteous and those who attack the anointed king are brought into focus in David. We

1 Steffen G. Jenkins, 'Retribution in the Canonical Psalter' (Ph.D. dissertation, University of Bristol, 2016); supervisor Professor Gordon Wenham. 
notice that David is introduced to the Psalms, via the superscription of Psalm 3, as a sinner pleading for grace. The placement of Psalms within the Writings invites further reflection on how Israel should model its prayers about exilic captors on David's prayers concerning enemies. This will prove illuminating when the difficult Psalm 137 is examined in Book V.

We offer seven tentative 'theses' from Psalms 1-3, namely:

1. Judgement on the wicked oppressor is rescue for the innocent victim.

2. The whole Torah, and not simply the lex talionis, governs prayers for retribution.

3. Praying for divine intervention against an enemy requires the supplicant to be innocent in the specific situation that is occasioning the enemy's actions, but not generally sinless.

4. The supplicant in such a situation is aware that he is a sinner asking for mercy, not strict justice.

5. Judgement transforms the isolated and beleaguered righteous into a congregation.

6. The attitude to enemies is far from the caricatures of the OT as vindictive and unloving.

7. Praying for divine intervention does not replace human action, even retributive judgement.

We select three of these areas $-3,4$, and $6-$ for further investigation in the Psalter as a whole. They concern the perceived opposition of attitudes between OT and NT: love for enemies flowing from awareness of grace versus hatred fuelled by self-righteousness. The common allegation that OT authors could not even envisage the repentance of the wicked is treated specially under \#6.

Before that investigation, we clarify the semantics of relevant lexemes in the Psalms to avoid interference from English terms, since the Psalms are so well known in translation. We examine Hebrew lexemes in the semantic fields of 'sin', 'atonement', 'salvation', and 'grace' (including an extended treatment of חסט , chesed). Any English reader who is familiar with the NT usage of such glosses will tend to infer that the latter three are dealing with sin. In fact, we find that only one common term in the general field of 'salvation' (סלח, salach) and none of the terms for 'grace' necessarily imply that the recipient of grace or salvation is guilty of $\sin$.

Two observations from this lexical investigation stand out for further examination in the Psalter. Firstly, terms for grace are brought 
together when Yahweh forgives Israel for the apostasy of the golden calf, which is alluded to throughout the Psalter. Secondly, sin and righteousness can co-exist within the very same Psalm. David can ask for forgiveness and acknowledge that his sin has led to his trouble while simultaneously pleading innocence from the malicious accusations of the same enemies.

Our investigation of Book I of the Psalter focuses mostly on Psalms 7 and the pair 18-19. Psalm 7, on close inspection, develops the themes we have seen in the overture. David is not claiming sinless perfection for himself, but rather innocence from a very specific slanderous accusation. The law of accusations of violence in Deuteronomy 19 shows why David is having to argue the way he does and why he warns his enemies of what Yahweh will bring about if they persist with their false accusations. Those very warnings already show an awareness that the enemy can repent and David's desire that he should. David prays for evil to end, not for the evildoer to be destroyed. His grasp of grace is further shown in that he is considerably stricter with himself than with his enemies.

Psalms 18 and 19 inform each other, as suggested by internal evidence of coupling and their placement in Book I. They show David's desire to bless enemy nations, in keeping with the invitation that is issued to them in Psalm 2. Their placement within Psalms 15-24 helps the reader to discern this offer of grace to the world.

Finally, we examine Book V and propose a novel structure, revising prior scholarly observations about features of composition. We note that a refrain is built up in successive psalms at the seams of Books IVV. Three sections are opened by a developing hodu refrain and concluded by developing hallelujahs. Within these three sections, the placement of לדוד (le-david) Psalms and of imprecations seems to be significant: what David teaches in earlier books is brought to bear on the nation's prayers in Book V. The hodu refrain highlights Yahweh's חֶֶֶ in forgiving Israel, and the Book develops the idea that the nations should experience חֶֶ too.

Yahweh's gracious response to the golden calf is significant in the Psalter. References to it are placed prominently in every Book of the Psalter and serve to highlight the typological similarity of David's sin with Bathsheba (leading to David's exile in Ps. 3) and Israel's apostasy (leading to Babylonian exile). In both Psalms 3 and 137 we find an innocent victim of unjust treatment (David from Absalom, Israel from 
Babylon), yet who is simultaneously guilty of sin, and is suffering the punishment prophesied about them. In both places, too, relief for the victim and punishment of the oppressor are prophesied. David's attitude in prayer for Absalom is therefore educational for Israel in considering Babylon.

We find that every imprecation in Book V (Pss. 109, 119, 129, 137, 139-144) is significantly placed within this structure. Our three themes under investigation are reinforced in Psalms 109 and 119, and by their placement within Book V.

Previous proposals for the structure of Book V have not been able to account for Psalm 137. This thesis would argue that the placement of imprecations in Book V explains the use of Psalm 137, so that one could almost suggest that Book $\mathrm{V}$ was constructed to teach Israel how to pray Psalm 137. That psalm is no oddity in the Book or in the Psalter, but integral to its message (when rightly understood within the structure of the Psalter) at four levels: the sequence from 136-144; the structure of Book V; the David-Israel-golden calf typology made prominent in every Book; and the introduction of David in Psalm 3 at the entrance to the whole Psalter. Psalm 137 is not softened, but the conditions under which one may pray about enemies, David's restraint in wishing them harm, and his desire that they repent and experience forgiveness puts divine grace in centre stage. חֶֶ brings Israel back from exile, just as David experienced forgiveness and a return from exile in Psalms 3 and 51. His treatment of Absalom and the northern tribes not only introduces his attitude to enemies in the Psalter, but also invites a parallel with Israel and her Babylonian captors. 